\title{
Carcinoma of the conjunctiva and HIV infection in Uganda and Malawi
}

Uganda Eye Project, PO Box 4008, Kampala, Uganda $\mathrm{K}$ M Waddell

International Eye Foundation, Blantyre, Malawi

$S$ Lewallen ${ }^{\star}$

Department of Histopathology, UCL Medical School, London

S B Lucast

Department of Ophthalmology, Makerere University Medical College, Kampala, Uganda C Atenyi-Agaba

Nuffield Department of Pathology, John Radcliffe Hospital, Oxford

C S Herrington‡

Department of Pathology, Queen Elizabeth Central Hospital, Blantyre, Malawi

G Liomba

Current addresses: *Center for Epidemiologic and International Ophthalmology University of British Columbia, Vancouver, Canada

†Department of Histopathology, UMDS, St Thomas's Hospital

London SE1

‡Department of

Pathology, University of Liverpool

Correspondence to: Professor S B Lucas, Department of Histopathology, UMDS St Thomas's Hospital, London SE1.

\author{
K M Waddell, S Lewallen, S B Lucas, C Atenyi-Agaba, C S Herrington, G Liomba
}

\begin{abstract}
Aim-To investigate the association of human immunodeficiency virus (HIV) infection and carcinoma of the conjunctiva in Africa, and the role of human papilloma virus type 16 (HPV-16).

Methods-Patients in Uganda and Malawi presenting to eye clinics with lesions suspicious of carcinoma were studied. Pathological confirmation of eye lesions was sought. HIV testing of patients who were biopsied and, in Uganda, of matched case control subjects was carried out as was testing of a sample of fixed biopsies for HPV-16 by polymerase chain reaction (PCR). The HIV-1 serology, histopathology of conjunctival biopsies (conjunctival intraepithelial neoplasia (CIN), invasive carcinoma, other lesions), and prevalence of HPV-16 infection were determined.
\end{abstract}

Results-Of Ugandan patients, 27/38 (71\%) with carcinoma (27 invasive carcinoma, 11 CIN) were HIV positive compared with 12/76 (16\%) of controls (odds ratio $13,95 \%$ confidence interval $5-38$ ). The calculated population aetiological fraction of carcinoma associated with HIV was $66 \%$. Of 32 Malawian patients (20 invasive carcinoma, 12 CIN), 25/29 tested $(86 \%)$ were HIV positive. HPV-16 infection was found in $7 / 20(35 \%)$ of carcinoma samples, $0 / 9$ pingueculae, and $2 / 6$ conjunctivitis samples.

Conclusions-HIV infection is strongly associated with an apparent increase in the incidence of conjunctival carcinoma in Africa. While ultraviolet light is probably the prime risk factor and HPV-16 is implicated in a proportion of cases, the interactions of ultraviolet light, HIV, HPVs, and other factors are unclear in the pathogenesis of carcinoma. The disease represents another model of multifactorial epithelial carcinogenesis.

(Br f Ophthalmol 1996;80:503-508)

Carcinoma of the conjunctiva is more frequent in sub-Saharan Africa than in temperate countries. This information derives from histopathologically based cancer registries in the 1960 s and 1970s, particularly in Uganda and Malawi, ${ }^{12}$ but there are no recent published incidence data. Exposure to ultraviolet light has been the major risk factor implicated. ${ }^{2-4}$

Personal observation (KMW) in Uganda since 1964 noted from 1983 onwards a striking increase in the number of patients presenting with conjunctival carcinoma. Previously, only occasional cases were seen, mostly in older people. After 1983 carcinomas became markedly commoner and at younger ages (including teenagers), and some appeared faster growing. Parallel increases in atypical Kaposi's sarcoma and ophthalmic zoster, which are associated with HIV infection, ${ }^{5}$ suggested a similar association. A review of ophthalmic features of AIDS in Rwanda up to 1985 made no mention of epithelial lesions, ${ }^{6}$ but by 1990 a strong association between carcinoma and HIV (odds ratio $=13$ ) was noted from a case control study of 11 patients. $^{7}$ Patients studied in 1991 in Uganda gave a similar association with HIV-1 infection among a sample of 48 cases. $^{8}$ The increased frequency applies to both invasive squamous cell carcinoma and conjunctival intraepithelial neoplasia, but not to other ocular neoplasms. ${ }^{78}$

A few cases of conjunctival carcinoma in patients with AIDS have been published from Europe and USA. ${ }^{9-11}$ Human papilloma virus (HPV) infection of the conjunctiva has been associated with in situ and invasive carcinoma, particularly HPV type $16 .^{12-14}$

The reports of HIV associated conjunctival carcinoma in Africa are brief. ${ }^{7}$ We undertook a further study of this emerging problem in Uganda and Malawi to document the clinicopathological findings, the HIV serology, and association with HPV-16 infection. For Uganda this was a case control study; in Malawi, HIV data were collected on consecutive presenting patients.

\section{Materials and methods}

PATIENTS IN UGANDA

From January to December 1994 , all patients in seven countrywide eye clinics who had suspicious conjunctival lesions had excision biopsy of the lesion (KMW). In September to October 1994 at New Mulago Hospital, Kampala, the same procedure was followed (CAA). Blood was taken for HIV testing after consent for surgery and serology was obtained. Blood from two controls per case was taken in the study period, matched for sex and age (plus or minus 10 years, youngest $=15$ ). The controls came from the same unit or lived in the same district. Sixteen controls were patients in the eye clinic without neoplasia or clinical features of HIV disease; the remaining 54 were general (non-eye clinic) anonymous outpatients at the same health units.

Initial serology was done by HIVChek $1+2$, HIVSpot, or Serodia. All except two case specimens and five controls were retested by a 
different method (107 out of 114); 89 of these were by western blot which was taken as definitive. The remaining 25 specimens were retested by HIVChek $1+2$ and Serodia.

The population aetiological fraction of carcinoma associated with HIV infection was calculated. ${ }^{15}$

\section{PATIENTS IN MALAWI}

From October 1993 to March 1994, all patients who presented to the Queen Elizabeth Central Hospital eye department with conjunctival growths were scheduled for excision of the lesion if it was suspicious of malignancy (SL). After informed consent was obtained, the Behring enzyme linked immunosorbent assay (ELISA) was used to test for HIV infection.

In both centres, clinical examination sought for features of the clinical case definition of AIDS for Africa. ${ }^{516}$

\section{HISTOPATHOLOGY METHODS}

Biopsies were fixed in formal saline, processed to paraffin, and sections stained with haematoxylin and eosin. The periodic acid Schiff (PAS) stain was used to evaluate basement membrane integrity and the presence of mucin. Lesions were categorised as pingueculae (elastotic degeneration of the subepithelial connective tissue and a normal or hyperplastic epithelium), partial or full thickness dysplasia (conjunctival intraepithelial neoplasia, $\mathrm{CIN}^{317}$ ), and invasive carcinoma with or without $\mathrm{CIN}$.

\section{HUMAN PAPILLOMA VIRUS EVALUATION}

Infection with human papilloma virus type 16 (HPV-16) was detected by the polymerase chain reaction (PCR). From the biopsy samples from Uganda and Malawi, 20 cases of invasive squamous cell carcinoma, and nine pingueculae were chosen at random for PCR. In addition, six biopsies of inflamed conjunctiva that included epithelium but no malignancy or elastotic degeneration were tested. Material from six reactive lymph node biopsies (that is, no epithelium present) from the Ugandan population was also tested as negative controls.

Paraffin embedded tissue sections of $5 \mu \mathrm{m}$ were dewaxed and digested with proteinase $\mathrm{K}$. Aliquots of $5 \mu \mathrm{l}$ were amplified using primers to the L1 gene of HPV-16. ${ }^{18} \mathrm{~A}$ hot start proce-

Table 1 Conjunctival squamous cell neoplasia (intraepithelial and invasive) according to HIV status in Ugandan patients with their controls

\begin{tabular}{|c|c|c|c|}
\hline & $\begin{array}{l}\text { Cases } \\
\text { No (\%) }\end{array}$ & $\begin{array}{l}\text { Controls } \\
\text { No (\%) }\end{array}$ & $\begin{array}{l}\text { Odds ratio } \\
\text { (95\% CI) }\end{array}$ \\
\hline \multicolumn{4}{|c|}{$\begin{array}{l}\text { Intraepithelial neoplasia: } \\
\text { HIV status }\end{array}$} \\
\hline $\begin{array}{l}\text { Positive } \\
\text { Negative }\end{array}$ & $\begin{array}{l}8(72.7) \\
3(27.3)\end{array}$ & $\begin{array}{r}4(18.2) \\
18(81.8)\end{array}$ & $\begin{array}{l}12.0 \\
(1.7-102.8)\end{array}$ \\
\hline \multicolumn{4}{|c|}{$\begin{array}{l}\text { Invasive carcinoma: } \\
\text { HIV status }\end{array}$} \\
\hline $\begin{array}{l}\text { Positive } \\
\text { Negative }\end{array}$ & $\begin{array}{r}19(70.4) \\
8(29.6)\end{array}$ & $\begin{array}{r}8(14.8) \\
46(85.2)\end{array}$ & $\begin{array}{l}13.7 \\
(4.0-49.7)\end{array}$ \\
\hline $\begin{array}{l}\text { Totals: } \\
\text { HIV status }\end{array}$ & & & \\
\hline $\begin{array}{l}\text { Positive } \\
\text { Negative }\end{array}$ & $\begin{array}{l}27(71.1) \\
11(28.9)\end{array}$ & $\begin{array}{l}12(15.8) \\
64(84.2)\end{array}$ & $\begin{array}{l}13.1 \\
(4.7-37.6)\end{array}$ \\
\hline
\end{tabular}

Table 2 Conjunctival squamous cell neoplasia (intraepithelial and invasive) according to HIV status in Malawian patients

\begin{tabular}{llll}
\hline & $\begin{array}{l}\text { Intraepithelial } \\
\text { No (\%) }\end{array}$ & $\begin{array}{l}\text { Invasive carcinoma } \\
\text { No (\%) }\end{array}$ & $\begin{array}{l}\text { Total } \\
\text { No (\%) }\end{array}$ \\
\hline HIV status & & & \\
Positive & $9(75.0)$ & $16(80.0)$ & $27(78.1)$ \\
Negative & $1(8.3)$ & $3(15.0)$ & $4(12.5)$ \\
Untested & $2(16.7)$ & $1(5.0)$ & $3(9.4)$ \\
Totals & 12 & 20 & 32 \\
\hline
\end{tabular}

dure was followed by 40 cycles of amplification. The resulting products were analysed by agarose gel electrophoresis and Southern blotting. Hybridisation was with a biotinylated internal 30mer oligonucleotide probe, and products were detected using streptavidin alkaline phosphatase and NBT/BCIP..$^{19}$

\section{Results}

In Uganda, 38 patients (27 invasive carcinomas and 11 CIN lesions) were found in the study period (Table 1). There were 14 males and 24 females (a ratio of 1 to 1.7 - not significant). The age range was 15 to 75 (mean 35) years. Twenty one lesions were on the right eye and 17 on the left; $30 / 36$ (83\%) were on the nasal side of the cornea and six temporal (two uncertain).

In Malawi, 46 patients were offered surgery and 36 accepted. Four of 36 lesions were pingueculae. The 32 carcinoma cases included 20 invasive lesions and $12 \mathrm{CIN}$ lesions (Table 2). There were 15 male and 17 female patients with carcinoma, the age range was 22 to 50 (mean 31 ) years; $24 / 28(86 \%)$ lesions were nasal and four temporal (four uncertain).

HIV SEROLOGY

Carcinoma was significantly associated with HIV infection in Ugandan patients: odds ratio (OR) $13.1,95 \%$ confidence interval (CI) $4.7-$ 37.6 (Table 1). The four youngest patients with carcinoma (aged 15, 17, 17, and 25 years) were HIV negative by western blot. HIV results were changed in five retests by western blot (one case and two controls to HIV positive, and one each to negative). The other retests were concordant. Table 2 shows the number of patients in the Malawian series with their HIV status. A further eight of the 10 Malawians who declined biopsy had HIV testing and five were positive.

From the Ugandan case control data, the aetiological fraction in the HIV exposed population was $92 \%[((\mathrm{OR}-1) / \mathrm{OR}) \times 100]$. With the HIV prevalence among Ugandan controls at $15.8 \%$, the population aetiological fraction of carcinoma associated with $\mathrm{HIV}$ infection was $66 \%[(0.158(\mathrm{OR}-1)) /((0.158(\mathrm{OR}-1))+1) \times$ $100]$.

HISTOPATHOLOGICAL FEATURES

These were similar in the lesions from both countries and the data are combined. Forty six of $47(98 \%)$ invasive carcinomas were squamous and one was mucoepidermoid carcinoma; $32 / 41$ (78\%) evaluable carcinomas had associated CIN in the biopsy, and 36/40 (90\%) 


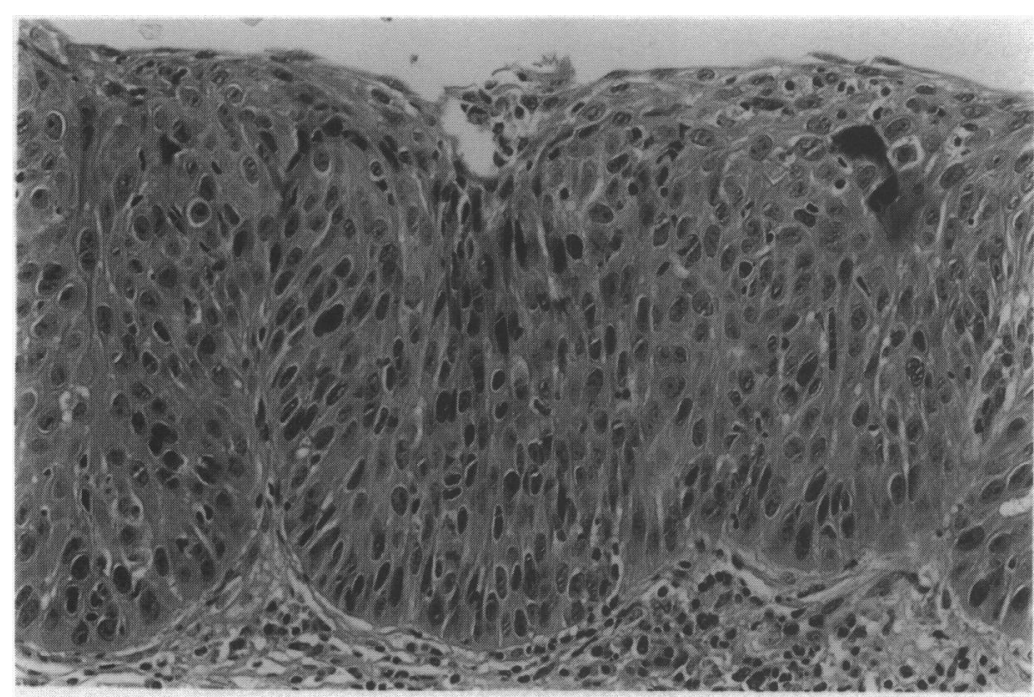

Figure 1 Conjunctival intraepithelial neoplasia (CIN), full thickness. Haematoxylin and eosin stain.
CLINICAL DATA AND FOLLOW UP

Macroscopically the lesions ranged from $3 \mathrm{~mm}$ to over $3 \mathrm{~cm}$ in diameter (Figs 4,5 ). Some lesions as small as $4 \mathrm{~mm}$ were invasive carcinomas. In both countries all lesions (unless recurrent or large) were centred on the 180 degree meridian (at 3 or 9 o'clock to the cornea in the exposed area). The majority touched the corneal edge or overgrew it, but could be up to $5 \mathrm{~mm}$ distant. The surface was roughened or fungating, and this distinguished even the small carcinomas from benign lesions. Several had variable amounts of melanin pigment. In Uganda, three patients had tumours invading the globe and required enucleation, but the rest (including three recurrences) were removable by local excision under local anaesthesia, with superficial keratectomy if needed. In Malawi, five cases were recurrences and all were removed locally with cryotherapy to the wound edges. Healing was rapid, leaving almost no sign of surgery and corneal clarity returned. One Ugandan and two Malawian patients suffered later recurrences with invasion into the globe or orbit requiring extended removal. No distant metastases were seen. The duration of the lesions was reported to be between 1 week and 2 years, but patient recall seemed too unreliable to allow analysis. One documented patient was a 25-year-old female, HIV positive, who went from an insignificant nodule that was not excised to a carcinoma invading the globe within 8 months.

known for $32 / 35$ patients whose lesions were tested for HPV-16: HIV and HPV-16 infections were not statistically significantly associated (but the numbers are small).

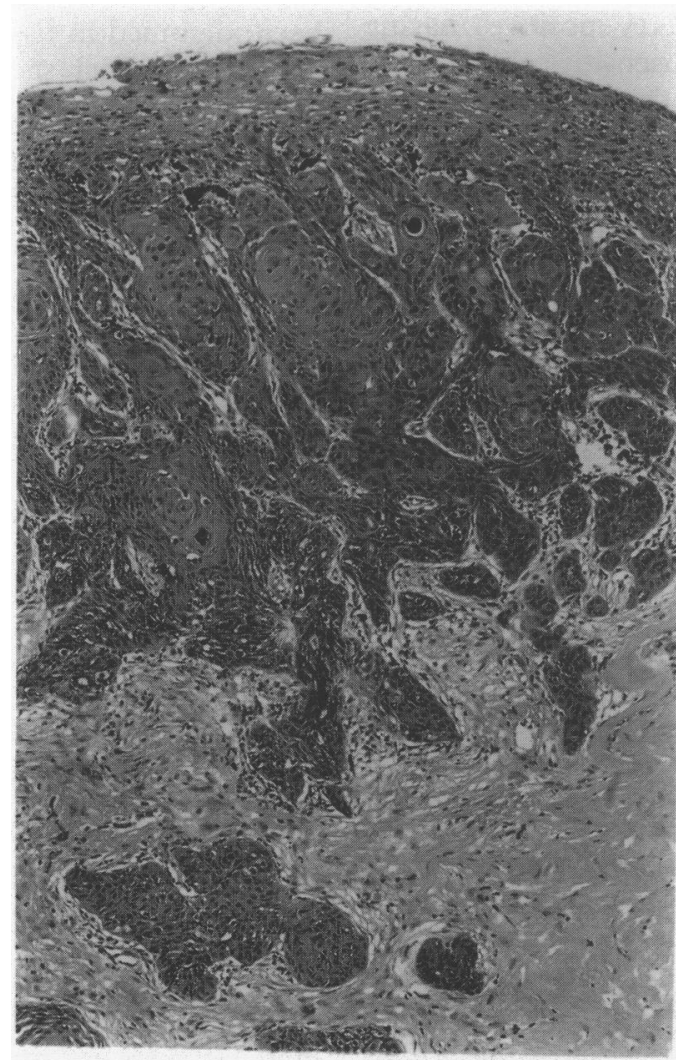

Figure 2 Invasive carcinoma of the conjunctiva; at lower right, the connective tissue shows elastosis. Haematoxylin and eosin stain.
Two of 38 Ugandan patients fulfilled the WHO AIDS case definition; in Malawi, 12 out of 30 evaluated patients did so, three having pulmonary tuberculosis. In Malawi there were no significant associations between histological diagnosis (CIN or invasive carcinoma) and the presence of AIDS defining signs.

\section{Discussion}

Conjunctival carcinoma has become a common clinical problem in these two countries. A similar increase has been seen in Nairobi, Kenya ( $\mathbf{M}$ Wood, personal communication). The strong association between HIV positivity and conjunctival carcinoma is congruent with the increased frequency of carcinoma observed in Uganda since 1983 when HIV infection became common. In Uganda the odds ratio of conjunctival carcinoma associated with HIV infection is 13.1 , similar to that in both previous studies. $^{78}$ The control seroprevalence of $15.8 \%$ accords with $12.6 \%$ reported in 1991 for the region from which most cases came. ${ }^{20}$ The testing of sera in Uganda was not uniform but $94 \%$ were done by two methods, and $83 \%$ of these included western blot, so a more uniform protocol would be unlikely to weaken the association. In Malawi there were no controls from which to calculate an odds ratio, but a minimum 25 of the 32 cases $(78 \%)$ were HIV positive. For comparison, antenatal women in the same hospital had an HIV-1 seroprevalence of $33 \% .^{21}$ patients were HIV positive, and the population
AIDS CASE SURVEILLANCE

Seventy eight per cent to $84 \%$ of carcinoma 


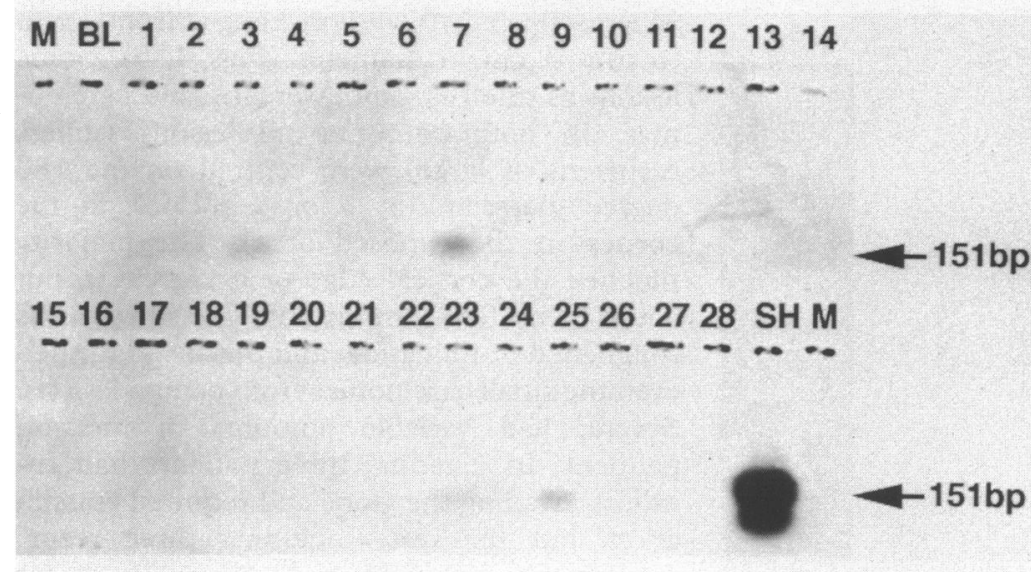

Figure $3 H P V-16$ polymerase chain reaction assay on 28 of the tested Uganda and Malawi samples. Southern blot showing positive hybridisation signals in lanes 3,7,23,24. $M=$ marker; $B L=$ water blank negative control, $\mathrm{SH}=\mathrm{SiHa}$ cell digest (positive control with 1 copy per cell).

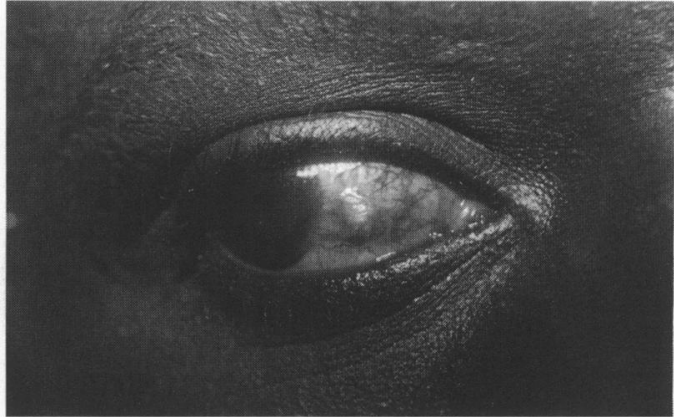

Figure 5 HIV negative patient with small invasive carcinoma of the conjunctiva.

seven per cent to $85 \%$ of invasive carcinomas had adjacent $\mathrm{CIN}$ in the biopsies as evidence of the continuum of $\mathrm{CIN}$ through to invasive lesions.

The aetiological role of HIV infection is unclear. There is no evidence that HIV is directly carcinogenic. One possibility is a failure of immune surveillance of malignant cells, which could follow from HIV mediated cellular immunosuppression and also, perhaps, from ultraviolet light itself. $^{23}$ If so, a wider range of tumours might be expected. The only other ocular tumours observed in the study period were one melanoma and a few Kaposi's sarcomas, so the increase appears specific for conjunctival carcinoma.

Secondly, other infective agents may be inducing the carcinoma, and immunosuppression from HIV facilitates their activity. Human papilloma viruses are implicated in the increased incidence of anal and cervical carcinomas associated with HIV infection. ${ }^{24}{ }^{25}$ With in situ hybridisation, HPV-6 and HPV-11 have been identified in tissues of benign conjunctival and lacrimal sac papillomas. ${ }^{26}$ In situ hybridisation studies of HPV on squamous carcinoma tissue have proved positive for HPV-16 in one report, ${ }^{28}$ but negative in others. ${ }^{1129}$ Using the polymerase chain reaction (PCR), HPV-16 was found in $88 \%$ of 43 paraffin embedded tissues of $\mathrm{CIN}$ and invasive carcinoma, ${ }^{13}$ and in four of five CIN lesions. ${ }^{14}$ Co-infection with HPV-18 occurs in some tumours. ${ }^{14}$ None of these studies from USA and Europe included samples from specified HIV infected patients.

This is the first study from Africa to detect HPV infection in conjunctival carcinoma tissues. None of three Malawian patients with carcinoma (two of whom had AIDS) in an earlier PCR study had detectable HPV-6, 11, 16, or $18 .^{30}$ Seven of $20(35 \%)$ of the present patients in Uganda and Malawi with carcinoma had HPV-16 in the conjunctival epithelium, and $2 / 15(13 \%)$ of non-cancer patients. This prevalence in African carcinoma patients is smaller than that found in the USA but, as there, no HPV-16 was detected in pingueculae or pterygia. ${ }^{13}$ There are no population data on the prevalence of conjunctival HPV infection in Africa. It is possible that HPV types other than HPV-16 are present in conjunctiva and may be associated with carcinoma; infections with different spectra of HPV types are
Figure 4 HIV positive patient with invasive carcinoma of the conjunctiva 


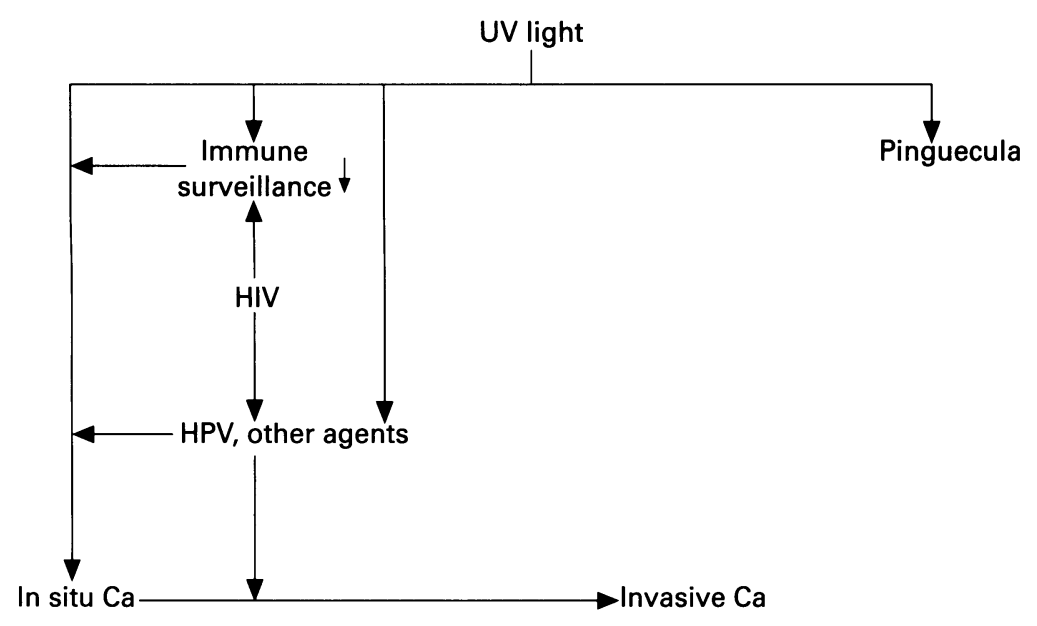

Figure 6 Hypothetical carcinogenetic processes in HIV associated conjunctival carcinoma (Ca). UV=ultraviolet light, HIV=human immunodeficiency virus, HPV=human papilloma virus. of conjunctival carcinoma and HIV infection in other countries in Africa; (2) a search for other infective agents, including other HPV types, in tumours; (3) population prevalence studies of HPV infections of the conjunctiva, and (4) an epidemiological study of factors in patient lifestyles that could be contributory, such as irritation from exposure to dust, cooking smoke, and other environmental agents. ${ }^{36}$

We thank Mr P Muhindo (Kagando Hospital), Mr R Wood (Mengo Hospital); Dr R Downing (Uganda Virus Research Institute) for performing the HIV serology, Professor V Beral (ICRF Cancer Epidemiology Unit, Oxford) for advice on patient/control sampling.

1 Templeton AC. Tumours of the eye and adnexa. In: Templeton AC, ed. Tumours in a tropical country. London: Heinemann, 1973: 203-14.

2 Clear AS. Solar keratosis, pterygium, and squamous cell carcinoma of the conjunctiva in Malawi. $\mathrm{Br} \mathcal{F}$ Ophthalmol 1979; 63: 102-9.

3 Lee GA, Hirst LW. Ocular surface squamous neoplasia. Surv Ophthalmol 1995; 39: 429-50

4 WHO. Environmental health criteria 160. Ultraviolet radiation. Geneva: World Health Organisation, 1994

reported in studies of anogenital lesions in Africa compared with those in industrialised countries. ${ }^{31}$

Recently, DNA sequences of a novel herpes virus have been detected in Kaposi's sarcoma, ${ }^{32}$ and in skin epidermal proliferations and carcinomas in patients with non-HIV associated immunodeficiency. ${ }^{33}$ It is possible that such an agent may also play a role in conjunctival carcinogenesis.

The HIV epidemic in Africa is associated with an epidemic of conjunctival carcinoma, ${ }^{8}$ and it is hypothesised that sunlight, HPV-16 and, possibly, other agents are involved in a complex carcinogenic process (Fig 6). Other unresolved phenomena remain. The youth of many carcinoma patients (down to mid-teens) is surprising, as carcinomas are rare at these ages in the absence of a predisposition such as xeroderma pigmentosum. ${ }^{34}$ In Uganda this was a striking new feature from the 1980 s (though the 1960s series did include a 13-year-old patient ${ }^{1}$ ). HIV does not explain this as the youngest patients were HIV negative. Possibly, $\mathrm{HIV}$ in the community is promoting transmission of another (infective?) agent in HIV negative people, parallel with the phenomenon of the increased incidence of Kaposi's sarcoma among HIV negative homosexual men in the USA. $^{35}$ Secondly, it is surprising that more patients with advanced fungating eye cancer were not seen since eye services are sparse and, in general, malignancies present late in these countries. Possibly patients are dying of AIDS before advanced carcinoma can develop.

While HIV associated conjunctival carcinoma is not a numerically major presenting feature of adult HIV disease in Africa, it is important. Firstly, it presents problems of clinical management. Eye centres are often remote and run by paramedical surgeons, so there is a need to develop appropriate techniques that minimise recurrence and preserve sight. Small carcinomas are often ignored while still easily curable. Secondly, the unresolved carcinogenetic risk factors and processes provide a model for studying HIV and HPV associated epithelial malignancy. Avenues for further study include (1) epidemiological studies
5 Piot P, Kapita BM, Ngugi E, Manm JM, Colebunders RL, Wabitsch R. AIDS in Africa. A manual for physicians. Geneva: World Health Organisation, 1992 $\mathrm{J}$, Nzaramba $\mathrm{D}$, et al. A prospective study of the ophthalmic findings in the acquired immune deficiency syndrome in Africa. Am $\mathcal{f}$ Ophthalmol 1995; 100: 230-8.

7 Kestelyn P, Stevens AM, Ndayambaje A, Hanssens M, Van de Perre P. HIV and conjunctival malignancies. Lancet 1990; 336: 51-2.

8 Atenyi-Agaba C. Conjunctival squamous cell carcinoma associated with HIV infection in Kampala, Uganda. Lancet 1995; 345: 695-6.

9 Winward KE, Curtin VT. Conjunctival squamous cell carcinoma in a patient with human immunodeficiency virus infection. Am $\mathcal{F}$ Ophthalmol 1989; 107: 554-5.

$10 \mathrm{Kim}$ RY, Seiff SR, Howes EL, O’Donnell JJ. Necrotizing scleritis secondary to conjunctival squamous cell carcinoma in acquired immumodeficiency syndrome. $A m$ Ophthalmol 1990; 109: 231-2.

11 Denis P, Charpentier D, Roudier M, Lemaire JC, Levin N, Nguyen-Khoa JL. Conjunctival epidermoid carcinoma and human immunodeficiency virus. ₹ Fr Ophtalmol 1994; 17: human

12 Garner A. Tumours of the cornea and conjunctiva. Curr Opin Ophthalmol 1993; 4: 41-6.

13 McDonnell JM, McDonnell PJ, Sun YY. Human papilloma DNA in tissues and ocular surface swabs of patients with conjunctival epithelial neoplasia. Invest Ophthalmol Vis $\mathrm{Sc}$ 1992; 33: 184-9.

14 Lauer SA, Malter JS, Meier JR. Human papilloma virus type 18 in conjunctival intraepithelial neoplasia. Am f Ophthalmol 1990; 110: 23-7.

15 Hennekens $\mathrm{CH}$, Buring JE. Epidemiology in medicine. Boston: Little, Brown, 1987.

16 World Health Organisation. Acquired immunodeficiency syndrome (AIDS). WHO/CDC case definition for AIDS. syndrome (AIDS). WHO/CDC case
Wkly Epidem Rec 1986; 61: 69-76.

17 Pizzarello LD, Jakobiec FA. Bowen's disease on the conjunctiva: a misnomer. In: Jakobiec FA, ed. Ocular and adnexal tumours. Birmingham, AL: Aesculapius, 1978. 553-71.

18 Walboomers JMM, Melkert PWJ, van den Brule AJC, Snijders PJF, Meijer CJLM. The polymerase chain reaction for human papillomavirus screening in diagnostic cytopathology of the cervix. In: Herrington CS, McGee JO, eds. pathology of the cervix. In: Herrington CS, McGee JO, eds.
Diagnostic molecular pathology. Vol II. Oxford: Oxford UniDiagnostic molecular pathology.
versiy Press, 1992: 153-71.

19 Herrington CS, Evans MF, Hallam NF, Chamock FM grade cervical intraepithelial neoplasia in patients with persistent low grade cytological abnormalities. $\mathrm{Br} \mathcal{F}$ Cancer 1995; 71: 206-9.

20 Wawer MJ, Serwadda D, Musgrave SD, Konde-Lule JK, Musagara $M$, Sewankambo NK. Dynamics of spread of HIV-1 infection in a rural district of Uganda. BMF 1991; 303: 1303-6.

21 US Bureau of Census. Trends and patterns of HIVIAIDS infection in selected developing countries. Washington DC: Health Studies Branch, Intemational Programs Centre, 1994 .

22 Lucas SB, Hounnou A, Peacock CS, Beaumel A, Djomand G, N'Gbichi J-M, et al. The mortality and pathology of $\mathrm{G}$, N'Gbichi J-M, et al. The mortality and pathology of
HIV disease in a West African city. AIDS 1993; 7: 1569-79

23 Adami J, Frisch M, Yuen J, Glimelius B, Melbye M Evidence of an association between non-Hodgki
phoma and skin cancer. $B M \mathcal{F}$ 1995; 310: 1491-5

24 Maiman M, Fruchter RG, Guy L, Cuthill S, Levine P, Serur E. Human immunodeficiency virus infection and invasive cervical carcinoma. Cancer 1993; 71: 402-6

25 Palefsky JM. Anal human papillomavirus infection amd anal cancer in HIV-positive individuals: an emerging problem. AIDS 1994; 8: 283-95.
6 Kestelyn P, Van de Perre P, Rouvroy D, LePage P, Bogaerts Gray W, McGee J'D. HPV status in the prediction of high Adami J, Frisch M, Yuen J, Glimelius B, Melbye $M$.
Evidence of an association between non-Hodgkin's lym- 
26 McDonnell PJ, McDonnell JM, Kessis T, Green WR, Shah $\mathrm{KV}$. Detection of human papilloma virus type 6/11 DNA in conjunctival papillomas by in situ hybridization with radioconjunctival papillomas by in situ hybridization

27 Madreperla SA, Green WR, Daniel R, Shah KV. Human papillomavirus in primary epithelial tumours of the lacrimal sac. Ophthalmology 1993; 100: 569-73.

28 Odrich MG, Jakobiec FA, LancasterWD, Kenyon KR, Kelly $\mathrm{LD}$, Kornmehl EW, et al. A spectrum of bilateral squamous conjunctival tumours associated with human papilloma virus type 16. Ophthalmology 1991; 98: 628-35.

29 Tuppurainen K, Raninen A, Kosunen O, Kankkunen J-P, Kellokoski J, Syrianen $S$, et al. Squamous cell carcinoma of the conjunctiva. Acta Ophthalmol (Copenh) 1992; 70: 24854.

30 Lewallen S, Shroyer KR, Keyser RB, Liomba NG. Aggressive conjunctival squamous cell carcinoma in three Aggressive conjunctival squamous cell carcinoma in three young Africans. Arch Ophthalmol 1996 (in press).

11 Cooper K, Henington CS, Graham AK, Evans MF McGee J'D. In situ HPV genotyping of cervical intraepithelial neoplasia in South African and British patients: evidence of putative HPV integration in vivo. $\mathcal{f}$ Clin Pathol 1991; 44: 400-5.

32 Chang Y, Cesarman E, Pessin MS, Lee F, Culpepper J, Knowles DM, et al. Identification of herpes virus like sequences in AlDS-associated Kaposi's sarcomas. Science 1994; 266: 1865-9.

33 Rady PL, Yen A, Rollefson JL, Orengo I, Bruce S, Hughes TK, Tyring SK. Herpesvirus-like DNA sequences in non-Kaposi's sarcoma skin lesions of transplant patients. Lancet 1995; 345: 1339-40.

34 Goyal JL, Rao VA, Srinivasan R, Agrawal K. Oculocutaneous manifestations in xeroderma pigmentosum. $\mathrm{Br} \mathcal{f} \mathrm{Oph}$ thalmol 1995; 78: 295-7.

35 Buchbinder A, Friedman-Kien AK. Clinical aspects of epidemic Kaposi's sarcoma. In: Beral V, Jaffe HW, Weiss RA, eds. Cancer, HIV and AIDS. New York: Cold Spring Harbor Laboratory Press, 1991: 39-52.

36 Napora C, Cohen EJ, Genven GI, Presson AC, Arentsen JJ, Eagle RC, et al. Factors associated with conjunctival intraepithelial neoplasia: a case control study. Ophthalmic Surg 1990; 21: 27-30. 